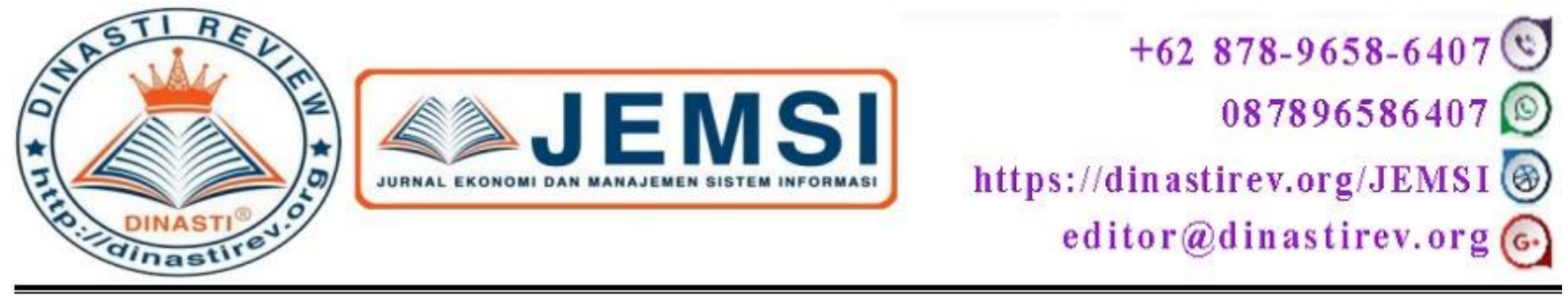

\title{
IMPLEMENTASI ETIKA BISNIS PADA PT AQUA GOLDEN MISSISSIPPI Tbk
}

\section{Dymas Widisatria}

Universitas Mercu Buana, Jakarta, Indonesia

ARTICLE INFORMATION

Received: 8 April 2020

Revised: 15 April 2020

Issued: 1 Mei 2020

Corresponding author : Dymas Widisatria

E-mail : dymaswidisatria07@gmail.com

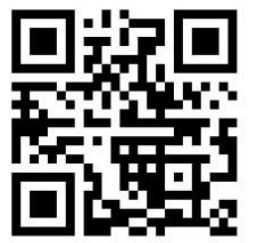

DOI:10.31933/JEMSI
Abstrak: Etika Bisnis adalah tindakan benar atau salah yang dapat mempengaruhi berbagai pihak. Etika perlu diperhatikan dalam perusahaan, karena berkaitan dengan kepuasan konsumen dan perlindungan konsumen. Etika dijunjung tinggi di dalam suatu perusahaan dikarenakan dengan menerapkan etika bisnis yang baik maka akan meningkatkan profit atau keuntungan perusahaan. Dengan memegang teguh menerapkan etika bisnis yang baik, bisnis dapat dijalankan dengan baik dan memiliki keunggulan bersaing. Penelitian ini ingin menganalisis implementasi etika bisnis pada PT. Aqua Golden Mississippi Tbk yang merupakan perusahaan air minum dalam kemasan (AMDK) yang sangat sudah dikenal masyarakat Indonesia. Dalam praktiknya ternyata Aqua melakukan pelanggaran etika bisnis yaitu melakukan eksploitasi sumber mata air yang pada akhirnya merugikan masyarakat. Hal ini menyalahi etika lingkungan yang ada tetapi Aqua berbenah diri dan melakukan kelestarian Lingkungan dengan programnya "Aqua Lestari" dan "Satu untuk Sepuluh". Sehingga saat ini keseimbangan antara produksi yang dilakukan Aqua dan alam serta warga sekitar dapat berjalan dengan harmonis.

Kata Kunci : : Etika Bisnis, Etika Lingkungan, Eksploitasi

\section{PENDAHULUAN}

Perkembangan dunia bisnis yang cepat pada akhir-akhir ini, tidak hanya menyangkut hubungan antara pengusaha, tetapi berkaitan secara luas pada suatu perusahaan. Mengatasi perkembangan bisnis yang terus berkembang perlu diimbangi dengan aturan-aturan atau norma-norma. Oleh karena itu dalam perusahaan etika dan moral perlu dijaga. Dalam menjalakan bisnis etika berbisnis perlu dijunjung tinggi dalam mengelola usaha dengan kinerja yang unggul dan berkaitan satu sama lain yang mentaati kaidah etika yang sejalan dengan hukum dan peraturan yang telah ditetapkan. Etika Bisnis adalah sesuatu yang penting bagi suatu perusahaan dan harus diperhatikan yang ada kaitannya kepuasan konsumen dan juga perlindungan konsumen. Etika adalah keyakinan tentang tindakan yang benar atau yang salah, atau juga tindakan yang baik dan yang buruk dalam menjalankan seluruh kegiatan baik internal maupun eksternal. Etika bisnis merupakan gambaran terkait moralitas dalam bersikap dan 
berpikir yang dilakukan dalam kegiatan berbisnis (Bertens 2007). Moralitas memiliki keterkaitan dengan apa yang dilakukan manusia seperti kegiatan manhusia dalam berbisnis yang dapayt dilihat dari sudut pandnag moral.

Etika bisnis tidak dapat dipisahkan dalam kegiatan berbisnis yang dilakukan oleh para pelaku bisnis. Menurut Franz Magnis-Suseno (1987) menjelaskan bahwa etika harus dibandingkan dengan moral yang diajarkan dan menggambarkan sistem nilai terkait bagaimana manusia harus dapat hidup dengan baik yang berkiatan dengan adat kebiasaan yang dalam jangka Panjang akan membentuk kebiasaan. Suseno (1987) menyatakan bahawa moral meliputi wejangan, patokan dan kumpulan peraturan yang berlaku baik tertulis maupun lisan yang mengatur bagaimana manusia harus bertindak agar dapat menjadi manusia yang meiliki moral yang baik. Sedangkan etika adalah sebuah pemikiran kritis dan mendasar tentang ajaran moral dan dapat diterima oleh masyarakat. Pemasalahan yang terjadi pada etika dan hukum yang berlaku perlu mendapatkan perhatian yang lebih dan menjadi dasar yang harus dimiliki para pelaku bisnis yang akan menghasilkan kesimpulan terkait tindakan dan perilaku apa yang tepat dalam membangun bisnisnya. Dalam mewujudkan etika dalam berbisnis harius dilakukan pembicaraan dari seluruh stakeholder baik pengusaha, pemerintah, masyarakat, maupun bangsa lain agar etika dalam berbisnis tidak hanya dilakukan oleh satu stakeholder tetapi seluruh stakeholder dapat menerapkannya dalam dunia bisnis. Melihat fenomena yang terjadi pada kasus belakangan ini, perusahaan dituntut untuk menerapkan dan melaksanakan etika bisnis dalam berbisnis dengan baik. Etika bisnis dalam berbisnis haru dilakukan tanpa paksaan dan bukan karena tuntutan regulasi dalm pengelolaan usaha, tetapi harus disadari bahwa dalam penerapan etika bisnis dapat meningkatkan profitabilitas dalam usaha. Dalam perilaku berbisnis mendapatkan keuntungan adalah hal yang wajar karena dalam keberlangsungan bisnis keuntungan diperlukan dalam menjalankan bisnis dan tidak menyebakan kerugian yang berdampak pada semua pihak. Sehingga dalam melakukan bisnis harus melakukan straetegi bisnis yang baik dengan memanfaatkan sumber daya yang ada tanpa mengganggu lingkungan sekitar sehingga tercapai keunggulan dalam bersaing (Ashshidiqy dan Ali 2019). Salah satu CEO terkenal menyatakan bahwa "Kita melaksanakan etika dalam berbisnis kepada seluruh pihak yang berkepentingan bukan dikkarenakan oleh karena hukum dan aturan, tetapi karena dalam menjalankan etika bisnis dapat menghasilkan keuntungan atau profit" ("We do the ethical things for our stakeholder not because it's the law, but because it's profitable"). Perilaku etis dalam kegiatan berbisnis adalah sesuatu yang penting demi kelangsungan hidup bisnis itu sendiri.

Etika bisnis yang diterapkan dalam perusahaan berperan sangat penting untuk membentuk perushaan yang bisa mandiri, dan memiliki daya saing yang dapat menciptakan keunggulan dalam bersaing sehingga menciptakan nilai yang lebih tinggi. Hal ini terbukti bahwa etika bisnis adalah unsur penting dalam siklus bisnis agar bisnis yang diajalankan dapat bertahan lama, dan etika yang diterapkan dpat berdampak pada sikap saling percaya, jujur, adil, dan tanggung jawab. Dalam suatu perusahan besar seperti PT Aqua Golden Mississippi Tbk etika bisnis da moral harus dijaga baik demi kelangsungan perusahaan dikarenakan menyangkut citra perusahanaan. Citra perusahaan pada dunia bisnis sangat penting karena apabila citra poerusahaan buruk dapat berpengaruh terhadap produk dan jasa yang dijual. Sehingga etika berbisnis harus dijaga dengan baik dengan begitu perusahaan memiliki moral dan citra yang baik dalam konteks sosial internal maupun eksternal. Dari penjelasan diatas membuktikan bahwa perubahan zaman menuntut individu dan perusahaan dapat berubah dan mengikuti perkembangan zaman. Tatanan nilai terkait etika juga mengalami perubaha mengikuti zaman 
yang terus berubah. Tdak semua etika yang lama menghilang dan digantikan dengan nilai etika yang baru dan dianggap sesuai dengan perubahan zaman. PT Aqua Golden Mississippi Tbk adalah perusahaan yang terkenal dan memiliki nama di Indonesia dan bergerak dalam bidang produksi air minum dalam kemasan yang berpusat di Jakarta Selatan. Selain itu, PT Aqua Golden Mississippi Tbk memberikan kualitas pelayanan yang baik selain itu juga meningkatkan kepuasan pelanggan dalam kinerjannya selama ini. PT Aqua Golden Mississippi Tbk berkomitmen mengutamakan keprofesionalan yang dijalankan sebagai kunci utama dalam keberlangsungan bisnisnya. Berdasarkan latar belakang yang diuraikan, maka penelitian ini ingin melihat penerapan etika bisnis yang dijalankan oleh PT Aqua Golden Mississippi Tbk. Sehingga penulis dapat mengambil judul Implementasi Etika Bisnis Pada PT Aqua Golden Mississippi Tbk. Perumusan masalah yang diteapkan beserta tujuan dari penelitian yang dilakukan adalah menganalisis pengimplementasiaan etika bisnis pada di PT Aqua Golden Mississippi Tbk.

\section{KAJIAN PUSTAKA}

\section{Definisi Etika}

Etika memiliki arti yaitu adat istiadat dalam bahasa Yunani yaitu "Ethos". Adat atau kebiasaan akan membangun aturan yang kuat dimasyarakat, dan dapat membentuk moral masyarakat yang berhubungan dengan adat istiadat yang berlaku di masyarakat (Keraf 1998). Dan secara terus menerus pengertian etika berubah bahwa etika adalah ilmu yang membicarakn masalah tingkat lahu manusia yang dapat dinilai baik atau buruk. Etika adalah cabang dari ilmu filsafat yang mempelajari pandangan beserta persoalan yang berhubungan dengan masalahmasalah yang terjadi di masyarakat terkait kesusilaan etika, dan moral. Etika menurut Sumaryono (1995) memiliki arti adat istiadat yang diterapkan disatu wilayah. Etika dibedakan menjadi tiga macam yaitu:

1. Etika diartrikan sebagai ilmu yang terakandung didalamnya terdapat hal-hal kebijakan, tentang penialian terkait apa yang dilakukan seseorang.

2. Etika memiliki arti perbuatan dalam hal kebajikan. Contohnya sesorang dinyatakan etis apabila seseorang itu melakukan tindakan kebajikan.

3. Etika memiliki arti sebagai filsafat yaitu di dalamnya terdiri pelajaran-pelajaran, persoalna yang berhubungan dengan kesusilaan.

\section{Definisi Etika Bisnis}

Etika dan etis tidak meiliki arti yang sama sehingga dalam pengertiannya etika bisnis juga memiliki banyak arti yang berbeda. Etika sangat berkiatan erat dengan moral dalam etika mengajarkan untuk mengetahui khususnya tentang apa yang yang harus dilakukan dan tidak boleh dilakukan. Etika berkaitan tentang etika sbegai praksis dan mengambilnya sebagai objek. Menurut Velasquez (2005) Etika bisnis adalah ilmu yang mempelajri tentang moral yang dapat dikatakan salah atau yang dapat dikatakan benar. Studi saat ini beracuan pada standar moral yang ditetapkan dalam kebijakan, institusi, dan melakukan perilaku bisnis. Business Ethics dalam bahasa Indonesia disebut bisnis etik. Dan dalam bahasa Belanda etika perushaaan adalah bedrijfsethick dan etika usaha dalam bahasa Jerman yaitu Unternehmensethik. Dengan pendeketana yang ada etika bisnis sangat dekat dengan etika korporasi (Bourdeau 2004).

Ilmu ekonomi dan bisnis merupakan organisasi yang menjual barang dan jasa kepada konsumen untuk mendapatkan keuntungan atau laba. Bisnis dalam arti historis adalah memiliki konteks komunitas, individu, ataupun masyarakat dalam arti luas denagn arti sibuk dalam 
mengerjakan aktivitas yang dilakukan oleh masyarakat dalam mendatangkan keuntungan. Bisnis dikatakan sukses apabila dapat dikerjakan aktivitasnya secara lancar dan melakukan dapat dikatakan bahwa sibuk mengerjakan aktivitas dan melakukan pekerjaan yang jelas dan dapat menghasilkan keuntungan dapat dilukiskan menjadi "to provide products or services for a profit" (Bertens 2000). Konsumen adalah stakeholder yang sangat berperan dalam bisnis yang modern saat ini. Dengan adanya konsumen maka bisnis dapat berjalan karena jika tidak adanya konsumen tidak ada yang menggunakan produk atau jasa yang perusahaan buat. Peter Drucker seorang perintis teori manajemen, memberikan pengertian bahwa konsumen memiliki pernan yang sentral dapat menciptakan pasar dan dapat doikembangkan menjadi bisnis bias didefinisikan secara tepat sebagai "to create a customer" (Bourdeau 2004)..

Menurut pendapat Sutrisna (2010) Etika bisnis mengajarkan terkait norma moral yang diaplikasikan dalam seluruh aktivitas dengan tujuan perusahaan yang dibentuk. Etika bisnis selalu berkaitan dengan perilaku etis daan tidak etisnya perlakuan seorang manager atau pemilik perusahaan dan satu organisasi (Griffin \& Ebert 2009). Menurut Velasques (2005), etika bisnis adalah studi yang khusus menjelaskan mengenai moral yang benar dan salah dalam hal ini berfokuskan pada standar moral yang diterapkan dalam mengambil kebijakan, institusi, dan pelaku bisnis. Menurut Irham Fahmi (2013), etika bisnis juga menerangkan bahwa adanya aturan-aturan yang bersifat tegas dalam suatu bisnis boleh atau tidak diperbolehkannya dalam bertindak dimana perturan tersebut bersumber dari aturan yang bersifat tertulis ataupun tidak tertulis. Sehingga apabila suatu bisnis melanggar aturan yang ditetapkan maka perusahaan tersebut dan penanggung jawabnya akan mendapatkan sangsi. Prinsip yang harus dikedepankan dalam membuat asas manfaat dan keuntungan harus sesui dengan etika yang berlaku (Sutrisna 2010). Perilaku yang baik akan mendatakang manfaat yaitu baik keuntungan ataupun kegunaan bagi pelaku usaha (Fahmi, 2013). Menurut Bertens (2013), utilitarianisme merupakan perbuatan yang dilakukan dan mendapat penilaian baik sehingga membawa manfaat dan manfaat tersebut dapat menyangkut orang banyak. Teori tersebut berpendapat bahwa etika bersifat relative dan tidak dapat dipaksakan. Dalam praktiknya banyak berbagai masalah yang timbul seperti rasa egois yang memiliki arti focus terhadap diri individu itu sendiri sehingga mengabaikan adanya interaksi yang terjadi dari pihak luar sehingga dalam pengambilan keputusan tidak difikirkan secara matang (Fahmi 2013).

Etika bisnis adalah kegiatan yang dilihat dari berbagai aspek yang berkaitan antara individu, perusahaan dan masyaraka. Etika bisnis dalam perusahaan diharuskan membentuk nilai dan norma yang berkaitan dengan perilaku karyawan dan pimpinan dalam menjalankan bisnis dan terciptanya hubungan baik, adil, dan sehat dengan pelanggan. Etika bisnis dalam perushaan yang diterapkan dapat membentuk nilai, norma, dan perilaku yang ada di dalam diri karyawan maupun pemimpin dalam membentuk hubungan yang baik dan sehat dengan mitra kerja, pemilik saham, dan seluruh masyarakat. Sinour (2009) berpendapat bahwa etika dalam berbisnis memberikan keuntungan untuk para pembisnis dalam mendapatkan keuntungan. Keuntungan yang dimaskud yaitu :

1. Etika bisnis memberikan kesadaran akan adanya dimensi etis yang melekat pada perusahaan 2. Etika bisnis memberikan kese,mpatan para pembisnis dalam mepertimbangkan moral dan ekonomi yang memadai sehingga dapat sesuai dengan lingkungan yanga ada.

3. Etika bisnis memberikan para pembisnis apndangan terkait araha yang tepat dalam mempertimbangkan moral dan etis dalam menetapkan kebijakan bisnis demi tercapainya tujuan yang ditargetkan. 
Von der Embse dan R.A. Wagley dalam artikelnya di Advance Managemen Journal (1988), menjelaskan bahwa terdapat tiga indikator pendekatan dalam menjelaskan tingkat laku etika bisnis yang diterapkan yaitu:

- Utilitarian Approach yang mengandung arti bahwa seluruh tindakan memiliki konsekuensi. Sehingga dalam berindak seseorang harus menggunakan cara yang dapat memberikan manfaat kepada seluruh masyarakat dengan cara yang sangat aman dengan biaya dengan rendah.

- Individual Rights Approach yaitu semua tindakan yang memiliki hak dasar dan dapat dihormati oleh seluruh masyarakat. Dalam tindakan yang didasarkan tingkah laku dan harus dihindari benturan dengan hak orang lain sehingga dalam menjalankan bisnis tanpa ada masalah.

- Justice Approach yaitu dalam membuat keputusan setiap stakeholder mempunyai kedudukan yang sama dan dalam bertindak harus berbuat adil sehingga dapat memberikan pelayanan kepada pelanggan secara baik dalam bentuk perorangan ataupun kelompok.

\section{Pentingnya Etika Bisnis dalam Berbisnis}

Etika dan bisnis bukan merupakan dua hal yang bertolak belakang dan berbdeda dari berbagai sumber terkait pengertian etika bisnis yang beredar di masyarakt membuat para pelaku bisnis mengalami kebingungan. Pada intinya etika adalah norma atau aturan-aturan yang harus diperhatikan dalam menjalankan sebuah bisnis (Jeffrey et al. 2004). Nilai-nilai tersebut bersumber dari nilai-nilai yang diajarkan nenek moyang kita untuk selalu melakukan perbuatan yang baik. Etika memiliki perbedaan dengan hukun yang berlaku baik itu aturan, regulasi, Perbedaannya terletak pada sanksi yang diberikan yaitu dalam hokum apabila kita berbuat salah akan dikenakan sanksi yang tegas selain itu dalam hokum semua peraturan dibentuk dalam aturan tertulis dan formal seperti: undang-undang, peraturan pemerintah, peraturan lalu-lintas dan lain sebagainnya (Kusmiati 2020). Sedangkan etika tidak memiliki sanksi yang jelas sanksi yang diberikan hanya saja sanksi moral dan sanksi dari Tuhan Yang Maha Esa. Sehingga etika sering sekali diabaikan dan tidak mendapatkan perhatiaan. Tetapi bisnis yang tidak memerhatikan etika bisnis akan berdampak jangka pendek dan mendapatkan keuntungan yang banyak. Sedangkan dalam jangka panjang bisnis yang tidak memperhatikan etika bisnis akan mendapatkan sanksi moral yang diberikan oleh masyarakat (Monga 2007).

\section{Prinsip - Prinsip Etika Bisnis}

Prinsip etika bisnis yang diterapkan di dalam perusahaan sangat erat berkaitan dengan nilai yang dianut oleh masyarakat dalam melakukan bisnis yang tidak dapat terlepas dalam kehidupan masyarakat. Sony Keraf (1998) menyatakan prinsip - prinsip etika bisnis yang diberlakukan sebagai berikut :

1. Prinsip otonomi yang merupakan kemampuan manusia dalam mengambil keputusan dalam bertindak dalam melakukan etika bisnis dengan meningkatkan kesadaran terkait apa yang dianggap baik ataupun.

2. Prinsip kejujuran yang dijalankan memiliki tiga indikator yang mendukung kegiatan bisnis yang bertujuan bahwa bisnis tidak dapat bertahan lama jika tidak didasarkan atas prinsip kejujuran. Tiga lingkup kegiatan bisnis yangb berlaku yaitu: pertama, jujur yang perlu dilakukan yaitu sebelum melakukan syarat-syarat perjanjian dan kontrak sehingga dalam melakukan bisnis tidak terdapat kecurangan. Kedua yaitu dalam melakukan 
penawaran barang dan jasa yang dilakukan harus berdasarkan pada kejujuran yang sebanding dengan harga dan mutu yang diberikan. Ketiga yaitu dalam hubungan kerja dalam suatu perusahaan harus didasarkan pada kejujuran.

3. Prinsip keadilan yaitu apabila sesuatu yang terjadi dapat diperlakukan secara sama sesuai dengan aturan keadilan yang ada dan sesuai kriteria dengan rasional objektif, dan semua aktivitas yang dijalankan dapat seluruhnya dipertanggungjawabkan.

4. Prinsip dalam berlaku bisnis saling menguntungkan (mutual benefit principle), menuntut bisnis yang harus sejalan dengan tujuan bisnis yang menguntungkan berbagai pihak.

5. Prinsip yang dilakukan yaitu integritas moral yang menuntut internal perusahaah sebagai pelaku bisnis, agar dalam menjalankan bisnis nama perusahaan akan terjaga dengan sangat baik.

\section{Sasaran dan Ruang Lingkup Etika Bisnis}

Menurut Chen (2018) terdapat tiga sasaran dan ruang lingkup pokok etika bisnis yang dijalankan yaitu:

- $\quad$ Pertama etika bisnis mengharuskan semua pelaku bisnis dapat menjalankan bisnis dengan cara yang baik dan tidak merugikan semua pihak. Bisnis etik sangat membawa pengaruh terhadap kesuksesan bisnis dalam jangka Panjang sehingga bisnis yang baik dapat meningkatkan kesadaran moral demi kepentingan bisnis. Dan dalam melakukan etika bisnis tidak menyangkut perilaku seorang individu dan perusahaan dalam organisasi secara internal dan eksternal.

- $\quad$ Kedua adalah menyadarkan para seluruh masyarakat akan hak dan kepentingan yang tidak dapat dilanggar dalam proses bisnis. Pada tingkat tersebut fungsi dalam menjaga hal dan kewajiban seluruh stakeholder agar tidak terdapat kesalahan dalam bentuk kecurangan yang berfungsi dalam menggambil hak dan kewajiban setiap orang yang dapat bersifat merugikan bagi orang tersebut bersifat merugikan orang tersebut sehingga dituntut mengutamakan keadilan dalam setiap bisnis yang dilakukan.

- $\quad$ Ketiga dalam membahas etika bisnis sering disinggung terkait system ekonomi yang harus dilakukan secara etis dalam praktek bisnisnya. Pada hal ini dikaitkan dengan tingkatan etis terkait oligopoly, monopoli, kolusi dan praktek semacamnya yang akan merugikan dan mempengaruhi perekonomian di suatu Negara. Sehingga perlu dilakukan pentingnya legal-politis dalam praktek yang baik, yang sangat mengikuti kepentingan hukum dan aturan bisnis serta meningkatkan peran pemerintah yang efektif untuk menjamin keberlakuannya aturan-aturan bisnis yang secara jelas dan konsekuen tanpa danya pandang bulu

\section{Etika Bisnis Terhadap Pihak yang Berkepentingan}

Pada dasarnya perusahaan melakukan etika bisnis yang ditujukan pada pihak yang berkepentingan dan digolongkan menjadi 4 tingkatan yaitu :

1. Kepentingan pemegang saham dalam jangka pendek yaitu menjelaskan perusahaan dalam jenis ini mempunyai kepentingan yang mengutamakan hubungan dengan pemerintah dalam melaksanakan bisnisnya.

2. Kepentingan pemegang saham dalam jangka panjang yaitu perusahaan dalam hal ini memiliki tingkat kematangan dalam melakukan bisnis serta melakukan tindakan 
proaktif dengan pemegang saham, sehingga terlaksana sponsorship, dan sudah mulainya penanaman modal dan melakukan investasi.

3. Obligasi terhadap berbagai pihak yang berkepentingan yaitu disini perusahaan sudah terlibat dalam pemanfaatan tujuan dan keamanan negara yang memperlihatkan aspek nonekonomis serta menghindari penjaulan produk dan jasa yang tidak sesuai dengan kepentingan negara, dan masyarakat.

4. Pembentuk masyarakat/komunitas pada hal ini perusahaan sudah sangat peduli terhadap masyarakat, yang memperhatikan masalah ideologi, dan masalah keuangan yang dianggap merupakan salah keduannya.

\section{Tanggung Jawab Sosial Perusahaan}

Tanggung jawab perusahaan yang terbentuk dalam perusahaan berlandaskan kepada upada perushaan dapat bertanggung jawab secara sukarela dan tanpa paksaan dalam mempertimbangkan etika sosial yang terbentuk, sedangkan tanggung gugat di dalam perushaaan memberikan kepada semua stakeholder untuk bertindak sesuai dengan hukun dan norma sosial yang berlaku sehingga perushaan terhindar dari in compliance yang dapat menyeret perusahaan kedalam ranah hokum (Chen 2018).

\section{Tanggung Jawab Individu}

Tanggung jawab perorangan tau individu ialah ytnggung jawab yang dilakukan oleh setiap individu dalam organisasi dalam menjamin bahwa perusahaan melaksanakan etika bisnis secara baik dan dapat mempengaruhi pihak yang berkepentingan dalam menjalankan dan memperhatikan etika bisnis yang dijalankan oleh perusahaan. Dalam pelaksanaan tanggung jawab tersebut, seluruh pemimpin ataupun karyawan dituntut memiliki integritas yang tinggi sehingga bisa melaksanakan peran dan tanggung jawab yang baik, dan bukan menjadi individu yang menyembunyikan menutupi penyimpangan yang dilakukan oleh perusahaan dalam hal masalah etika bisnis (Alakavuklar \& Alamgir 2018).

\section{METODE PENELITIAN}

Peneliti ini menggunakan jenis penelitian kualitatif deskriptif, yang secara umum penelitian kualitatif adalah penelitian yang bersifat deksriptif bermaksud untuk memahami fenomena yang terjadi pada subjek penelitian dan diungkapkan secara holistic, dengan cara deskripsi yang dijabarkan dalam bentuk kata-kata dan bahasa yang dibahas secara alamiah dan menggunakan berbagai metode alamiah dalam menadapatkan hasil penelitiannya (Corner 2009). Penelitian ini akan mendeskripsikan penerapan etika bisnis pada PT Aqua Golden Mississippi Tbk. Penerapan etika bisnis dideskripsikan meliputi penerapan etika bisnis yang mana yang diterapkan di PT Aqua Golden Mississippi Tbk. Penelitian ini memiliki subjek yang dapat dianalisis yaitu lembaga, organisasi dan dokumen. Penelitian memiliki subujek yang diharapkan dapat menghasilkan kesimpulan (Azwar, 2013). Pada penelitian ini objek yang ingin diteliti adalah PT Aqua Golden Mississippi Tbk, merupakan perusahaan yang bergerak di bidang air minum dalam kemasan. Objek penelitian merupakan atribut baik itu dalam bentuk orang, objek kegiatan yang ingin dinilai sifat dan sikapnya serta mempunyai variasi yang ditetapkan oleh peneliti agar dapat dipelajari dan ditarik kesimpulannya untuk membuktikan hasil yang ingin dibuktikan (Sugiyono, 2013). Pengambilan data kualitatif dapat diperoleh dari beberapa teknik pengumpulan data yang ada dan dapat mengintrepretasikan hasil yang diinginkan, seperti wawancara, analisis dokumen, dan observasi yang dijabarkan dalam bentuk 
laporan catatan lapangan (transkrip). Sumber data yang digunakan oleh peneliti yaitu sumber data sekunder dari dokumen-dokumen perusahaan seperti profil perusahaan, sejarah perusahaan, serta dokumen-dokumen lain yang terkait dengan penelitian. Objek dalam penelitian ini adalah penerapan etika bisnis pada perusahan PT Aqua Golden Mississippi Tbk. Penelitian ingin mengetahui bagaimana penerapan etika bisnis mana yang diterapkan PT Aqua Golden Mississippi Tbk.

. Data yang digunakan dalam memperoleh hasil jurnal ini, penulis menggunakan metode pengumpulan data yang berupa studi kepustakaan yaitu dengan mengumpulkan data dari beberapa buku, referensi yang berada di internet, beserta jurnal yang mengkaji penelitian sejenis terkait penelitian etika dalam bisnis. Analisis data yang dilakukan dengan mengorganisasikan data, menjabarkannya ke dalam sebuah unit-unit kecil, dan melakukan sintesa, menyusun hasil tersebut ke dalam pola, dan terkahir memilih yang terpenting untuk dikaji, dan terakhir membuat kesimpulan yang dapat dijelaskan kepada seluruh orang. Menurut Sugiyono (2013), aktivitas dalam analisis data terbagi atas 3, yaitu: mereduksi data, penyajian data, dan kemudian melakukan penarikan kesimpulan/verifikasi. Dalam penelitian ini, peneliti menggunakan triangulasi untuk menguji keabsahan data yang digunakan. Peneliti memilih untuk menggunakan teknik triangulasi sumber. Sumber data yang dilakukan yaitu traiangulasi sumber merupakan metode yang didasarkan dengan mengakses sumber data yang bervariasi sehingga dapat meperoleh data yang diinginkan dan dapat dikaji (Pawito, 2007). Penggunaan triangulasi didasarkan pada sumber yang sesuai dengan kebutuhan dari penelitian yang bertujuan untuk menguji kredibilitas data yang didapatkan lalu cara mengecek data yang didapat. Setelah itu data yang telah diadapat dideskripsikan, dikategorisasikan, setelah itu dianalisis hingga mendapatkan kesimpulan.

\section{HASIL DAN PEMBAHASAN}

PT. Aqua Golden Massissippi Tbk, didirikan pada 23 Februari 1973 oleh Tirto Utomo atau Kwa Sien Biauw (1930-1994), yangg lahir di Wonosobo, beliau merupakan orang Indonesia yang dapat mengubah kebiasaan masyarakt Indonesia untuk mengonsumsi air minum dalam kemasan. Tanggal 4 September 1998, Aqua secara resmi mengumumkan "penyatuan" dengan Danone yang merupakan perusahaan multinasional dan bertepatan pada pada tahun 2000 yaitu era millenium PT. Aqua Golden Mississppi Tbk meluncurkan produk dengan label Danone-Aqua. Dan semenjak itu PT. Aqua Golden Mississppi Tbk resmi bergabung dalam Danone Group, yang merupakan perusahaan multinasional asal Perancis, dan berambisi dalam memimpin pasar global dengan tiga bisnis yang dijalankan yaitu bisnis dibidang dairy product, water atau air minum dalam kemasan dan, biscuit. PT. Aqua Golden Mississppi Tbk sebagai produsen air minum dalam kemasan yang menjadi nomor satu di dunia, Danone- Aqua berjuang keras dalam melawan pesaing sejenisnya seperti Coca-Cola dan Nestle. Aqua menjadi pelopor bisnis air minum dalam kemasan di Indonesia , serta menjadi produsen terbesar di Indonesia. Selain itu pasar yang dimasuki oleh Danone-Aqua tidak hanya Indonesia tetapi Singapura, Malaysia, Australia, Timur Tengah dan Afrika juga dimasukki oleh Danone-Aqua. Penjualan Danone-Aqua di Indonesia Aqua menguasai pangsa pasrnya hingga 80 persen dan itu hanya produk dalam bentuk galon. Sedangkan keseluruhan produk Danone-Aqua yang dijual menguasai pasar sebesar 50\% pasar. Untuk memenuhi kebutuhan pasar konsumen DanoneAqua memiliki empat belas pabrik yang tersebar di Indonesia yang meliputi meliputi Jawa, Sumatra, Bali dan Sulawesi. 
PT. Aqua Golden Mississippi Tbk dalam penerapkan nilai-nilainya yaitu mengikuti nilai-nilai yang diterapkan Danone Group yang menggambarkan visi dan etika binis perusahaan yang unik. Nilai-nilai Danone-Aqua ini berdasarkan sejarah yang telah dilalui Danone-Aqua yang menggambarkan komitmen perusahaan dalam komunikasi yang bersifat terbuka dan kerja bersama yang dimiliki. Nilai-nilai Danone yang dibangun didasarkan pada masukan karyawan Danone, didalamnya mengenai nilai yang penting dan dapat menggerakkan perusahaan. Hasil kolaborasi yang dilakukan menghasilkan empat nilai-nilai yang sampai saat ini dianut oleh Danone-Aqua yang dijunjung tinggi, dihormati, serta menyatu dalam kegiatan karyawan sehari-hari. Nilai tersbeut dapat menjadi pedoman dalam pengambilan keputusan, serta menjadi pandangan yang professional bagi perusahaan. Nilai tersebut dapat melindungi dan menjaga budaya kerja yang terbentuk di Danone-Aqua. Nilai-nilai tersebut meliputi:

\section{a. Kemanusiaan}

Nilai kemanusiaan yang berada di PT. Aqua Golden Mississippi Tbk yaitu berbagi yaitu dengan jujur yang dilakukan baik untuk diri sendiri dan orang lain dapat menciptakan keterbukaan, dialog antara karyawan dan kerjasama tim. Kedua dalah tanggung jawab, nilai ini menunjukkan bahwa tanggung jawab yang diberikan terhadap keselamatan manusia dan produk dengan seksama, selain itu juga bertanggung jawab terhadap alam dan masyarakat. Ketiga yaitu penghargaan terhadap orang lain yaitu dengan adanya perbedaan budaya yang terjadi di perusahaan PT. Aqua Golden Mississippi Tbk sehingga memperlakukan setiap orang sama dengan penghargaan yang sama pula, selain itu berkerja sama dalam membantu pengembangan mitra bisnis yanga ada.

\section{b. Kedekatan}

Nilai kedekatan yang berada pada PT. Aqua Golden Mississippi Tbk yaitu kemudahan akses dalam manajemen yang dilakukan di PT. Aqua Golden Mississippi Tbk gaya manajemen yang dilakukan yaitu terbuka dan mudah ditemui. Kedua yaitu kredibilitas pada PT. Aqua Golden Mississippi Tbk yang ditunjukkan pada kejujuran pada diri sendiri dalam mengambil tanggyng jawab dalam berbagai tindakan. Ketiga yaitu empati, empati disini berkaitan dengan pelanggan, dan para pemasok dengan memabngun bounding yang kuat berdampak pada hubungan yang baik dalam membeli dan menjual.

\section{c. Keterbukaan}

Nilai keterbukaan yang berada pada PT. Aqua Golden Mississippi Tbk yaitu rasa ingin tahu, dalam arti menimbulkan rasa ingin tahu dengan apa yang dikerjakan dan berperan secara aktif merencanakan masa depan. Sehingga cara kerja yang lama dan sudah tidak digunakan dan meningkatkan kreativitas dan ide-ide baru dalam melakukan pekerjaan. Kedua yaitu kelincahan, yang menggambarkan setiap karyawan memiliki sifat penuh semangat dan berenergi, serta cepat beradaptasi dalam berbagai kondisi. Ketiga adalah dialog yaitu yang memiliki arti setiap karyawan harus mendengar secara aktif dan terdapat diskusi yang terbuka dikarenakan gaya manajemen yang dianut adalah informal sehingga manajemen lebih menyukai diskusi terkait beragam pandangan yang berbeda.

d. Antusiasme

Nilai antusiasme yang berada pada PT. Aqua Golden Mississippi Tbk yaitu keberanian, yang memiliki arti setiap karyawan memiliki kebebasan dalam berpikir dan bertindak secara mandiri dan berani mengambil resiko yang cerdas dengan cara yang berbeda-beda. Sehingga karyawan percaya diri dalam mengatasi segala kegagalan dan kesulitan. Kedua yaitu semangat, dengan penuh keyakinan baik atasan ataupun karyawan dapat bekerja dengan penuh kesenangan saat target yang diberikan dapat terlampaui sesuai dengan yang diharapkan dan 
dapat mencapai keunggulan. Ketiga yaitu memiliki hasrat menerima tantangan, dengan rasa optimis dan penuh semangat seluruh karyawan dapat menerima semua tantangan yang bertujuan untuk membuat para karyawan tumbuh dan dapat menjadi seorang pemimpin. Menurut Mirza (2020), pengimplementasian etika bisnis dalam menciptakan produk baru, ada beberapa hal yang harus diketahui yaitu :

1. Manfaat dari produk tersebut apa.

2. Apakah produk tersebut memiliki manfaat ataupun pengaruh pada konsumen.

3. Adakah hal yang terjadi apabila konsumen menggunakan produk tersebut.

4. Apakah produk tersebut dapat berguna di dalam berbagai kondisi yang akan dihadapi

5. Tingkat keamanan produk

6. Apakah produk tersebut memiliki dampak buruk apabila konsumen tidak memperhatikan saran penggunaan.

Istilah eskploitasi yaitu penggunaan sumber daya alam yang digunakan secara berlebihan. Eksploitasi sangat memiliki arti bias kepentingan pada satu pihak atau lebih terhadap objek yang dijakan objek eksploitasi. Hubungan yang dimiliki oleh beberapa pelaku dapat dikatan eksploitatif yaitu menilai bahwa hubungan tersebut tidak adil, berbahaya, bahkan merugikan seseorang yang merasa sebagi pihak yang dieksplotasi. Pendapat lain terkait eksploitasi yang dipahami tindakan manusia yang berlebihan, dam sewenang-wenang dalam memanfaatkan sesutau. Pada praktiknya PT Aqua Golden Mississippi Tbk. telah melakukan pelanggran bisnis etik yang dilakukan pada lingkungan dan mengabaian kode etik dalam melakukan proses produksi yaitu pada penggunaan sumber daya alam.

Keprihatinan yang terjadi di dunia dengan adanya eksploitasi sumberdaya alam yang berlebihan dapat dirasakan setelah digelarnya United Nations Conference on Environment and Development atau Earth Summit di Rio de Janeiro di tahun 1992 yang di dalamnya membahas tentang perubahan iklim. Dari pembahasana diatas, dapat kita ketahui bahwa etika dalam berbisnis sangat berperan penting dalam pemciptakan produk baru untuk mengetahui manfaat dan keuntungan yang dapat dinikmati oleh konsumen. Selain itu juga untuk mengetahui dampak burukmdari prosuk yang dipasarkan jika mngabaikan peringan yang tertera pada produk. PT. Aqua Golden Mississippi Tbk dapat menghasilkan air bersih dalam memenuhi kebutuhan air minum masyarakat dengan menjamin tingkat keamanan produk tersebut membuat para konsumen percaya untuk menggunakan produk tersebut. Dengan kemasan yang praktis membuat konsumen mudah dalam mengonsumsinya, selain itu PT. Aqua Golden Mississippi Tbk memperbaiki kehidupan masyarakat untuk dapat hidup bersih dan sehat dengan mengonsumsi air bersih. Sumber mata air yang dieksploitasi secara berlebihan oleh PT. Aqua Golden Mississippi Tbk alah sumber mata air yang terdapat di berbagai tempat salah satunya yaitu sumber mata air di Polanharjo, Kabupaten Klaten, Jawa Tengah dimana masyarakat yang tinggal disana menopang hidup dari sector pertanian sehingga sumber mata air sangat penting bagi mereka. Sejak pengeksploitasian tersebut debit air menurun secara drastis, dan para petani terpaksa harus memiliki modal untuk membeli atau menyewa pompa dalam memenuhi kebutuhan irigasi sawah.

Dalam pemenuhan kebutuhan sehari-hari masyarakat disana harus membeli air dengan harga yang sangat mahal karena sumur warga disana sangat kering akibat pengeksploitasian sumber air secara besar-besaran. Hal tersebut sangat memprihatinkan mengingat Kabupaten Klaten adalah wilayah yang kaya akan sumber daya air. Karena disana satu Kabupaten dapat memiliki 150 sumber mata air. Dalam kasus ini PT. Aqua Golden Mississippi Tbk kurang berfikir etis dan telah melanggar tanggung jawab social sebagai perusahaan. Sumber daya alam 
memang dapat dinikmati oleh siapa pun, tetapi dalm pemanfaatannya tidak boleh dieksploitasi secara berlebihan. Dalam hal ini yang menjadi masalah adalah air, yang merupakan sumber daya yang dibutuhkan oleh orang banyak dalam peneuhan kebutuhan hidup yang layak. Meskipun PT. Aqua Golden Mississippi Tbk memiliki tujuan yang baik dalam menyediakan air besih untuk memenuhi keperluan minum orang banyak. Tetapi PT. Aqua Golden Mississippi Tbk tidak memikirkan apa dampak yang terjadi apanila sumber daya yang ada diekploitasi secara berlebihan. Sehingga PT. Aqua Golden Mississippi Tbk terkesan tidak bertanggung jawab dan terlihat egois karena hanya mementingkan kepentingan perusahaan. Hal tersebut membuat bentrokan antara masyarakat dengan pihak PT. Aqua Golden Mississippi Tbk dalam pemenuhan air bersih.

Kegiatan eksploitasi sumberdaya alam yang berlebihan dan mengabaikan lingkungan sangat mengancam keberlanjutan sumberdaya alam itu sendiri. Hal tersebut dapat dicerminkan pada pasal 33 ayat (3) Undang-Undang Dasar 1945 yang berisikan tentang "Bumi dan air dan kekayaan yang terkandung di dalamnya dikuasai oleh Negara dan dipergunakan untuk sebesarbesarnya kemakmuran rakyat". Hal yang terpenting dalam pemanfaatan sumber daya alam guna pembangunan Indonesia yaitu dapat mengutamakan pengelolaan sumber daya alam yang dapat dijaga dan diperbahaurui. Hak yang dipergunakan dalam menguasai negara menjadi instrument dasar untuk mengeksploitasi sumber daya alam yang ada di Indonesia tertera pada UU No.7 Tahun 2004. Konsep yang dituangkan secara histori menyatakan bahwa pemerintah telah mengingkari semangat demokrasi yang telah dibangun untuk mencapai kesejahteraan rakyat dan ekonomi. Hal tersebut mengindikasi paradigma pertumbuhan yang dijalankan di Indonesia memberikan ruang yang berlebih pada praktek eksploitatif dan destruktif pada sumber daya alam melalui penyerahan praktek wewenang pada perusahaan asing secara besarbesaran. Tetapi Danone Group yang menjadi induk perusahaan PT. Aqua Golden Mississippi Tbk memiliki Dual Commitmen yang diterapkan sampai saat ini. Kinerja ekonomi yang telah dicapai dengan memperhatikan terhadap aspek social masih berjalan hingga saat ini. Danone Group dalam menjalankannya menggunakan pendekatan bisnis yang dikombinasikan dengan tujuan ekonomi, tujuan social, serta lingkungan. Empat pilar Danone yang dijalankan sebagai prioritas yang strategis yaitu:

\section{a. Kesehatan (Health)}

PT. Aqua Golden Mississippi Tbk memastikan produk yang dihasilkan memiliki dampak yang baik bagi kesehatan serta berkualitas. Hal tersebut dijaga kualitasnya dari mulai pengambilan sumber mata airnya sampai proses pengemasan dan distribusinya, Selain itu informasi terkait produk di luar kemasan sangat penting bagi Aqua untuk mengedukasi masyarakat dalam membaca label pangan, serta memberikan pemahaman mengenai kesehatan dan kualiats produk yang dihasilkan. Selain itu melakukan promosi dan komunikasi yang efektif guna menjaga kepuasan dan privacy pelanggan.

\section{b. Lingkungan Hidup (Nature)}

Dalam menjaga lingkungan hidup PT. Aqua Golden Mississippi Tbk memiliki program yang sangat berkontribusi dalam pengelolaan daerah aliran sungai di sekitar lokasi pabrik itu berdiri. Dengan adanya program AQUA Lestari perusahaan mengharapkan kualitas dan kuantitas air tanah dapat terjaga sehingga dapat dimanfaatkan secara optimal oleh semua pihak . Selain itu juga dalam kegiatan produksinya Aqua sangat meminimalkan pencemaran lingkungan yang dapat mengubah iklim, 


\section{c. Manusia (People)}

Aqua dalam hal kemanusiaan menjadikan karywan sebagai asset perusahaan dan melakukan inisiatif sosial dengan program "AQUA Lestari" dan Danone Ecosystem Fund yang digunakan untuk sosial dengan dukungan teknis dan pembiayaan dari kantor pusat Danone di Perancis.

\section{d. Untuk Semua (For All)}

Pada pilar ini membuktikan bahwa Aqua dapat masuk ke semua kalangan baik kalangan menengah atas ataupun menengah kebawah dapat menikmati produk yang dihasilkan oleh Danone Aqua.

Program Aqua Lestari yang dijalankan oleh Danone Aqua memiliki 4 pilar uatama yang berkontribusi sosial yang diberikan kepada masyarakat dan lingkungan, yaitu:

a. Kegiatan Pelestarian Air dan Lingkungan yang didalamnya terkait penelitian sumber daya air, rehabilitasi saluran irigasi, penanaman seribu pohon, pemberian Pendidikan lingkungan hidup, pembuatan sumur resapan, dan lain-lain.

b. Kegiatan Praktik Perusahaan Ramah Lingkungan yaitu dnegan mereduksi karbon yang dilaksanakan dengan melakukan penghematan air, energi, bahan baku plastic dan kemasan, dengan manajemen lingkungan dan audit lingkungan Green untuk mengurangi karbon.

c. Kegiatan Pengelolaan Distribusi Produk yaitu dengan mode transportasi alternative seperti kereta api, safety riding, perbaikan jalan yang ada di daerah tersebut, serta melakukan pemberdayaan sampah kemasan, dan lain-lain.

d. Pelibatan dan Pemberdayaan Masyarakat dalam melaksanakanprogram tersebut Aqua melibatkan kegiatan usaha mikro dan koperasi, selain itu kegiatanpertanian organik terpadu guna melestarikan lingkungan serta melakukan akses modal pasar, dan akses air bersih yang bertujuan untuk penyehatan lingkungan WASH (Water Access, Sanitation and Hygiene). Program WASH yang gtelah dilaksanakan dikembangkan menjadi program baru yaitu program "Satu untuk Sepuluh" denagn tujuan menjadi solusi dalam menyediakan air bersih di seluruh Indonesia, dan khususnya untuk daerah yang sangat minim air bersih ataupun daerah yang kekeringan. Dengan menjaga kelestarian lingkungan maka proses bisnis dapat berjalan dengan baik tanpa merugikan pihak pemangku adat ataupun masyarakat sekitar (Amirudin dan Ali 2017). Program tersebut dibentuk berdasarkan fakta bahwa air sangat dibutuhkan oleh seluruh orang dan menjadi kebutuhan dasar. Karena pada realitanya banyak sekali masyarakat yang masih sangat sulit mendapatkan air bersih. Program tersebut telah dilaksanakan di Indonesia bagian Timur dikarenakan kelangkaan air bersih masih terjadi sampai saat ini yang berdampak pada kesehatan masyaralat dsekitarnya yaitu penyakit demam berdarah, diare, hingga malaria. Dari masalah yang telah dijabarkan PT. Aqua Golden Mississippi Tbk dan berkomitmen dalam mewujudkan kesejahteraan masyarakat Indonesia dengan cara menjual produk ukuran $600 \mathrm{~mm}$ dan $1.500 \mathrm{~mm}$ maka para konsumen sudah membantu program Aqua berjalan dengan baik yang memiliki arti konsumen sudah menyumbangkan air bersih kepada yang membutuhkan dan membangun pipa-pipa air yang menjangkau sampai pemukiman penduduk. 


\section{KESIMPULAN DAN SARAN}

Kesimpulan dari analisa diatas menunjukkan bahwa dalam beroperasinya PT. Aqua Golden Mississippi Tbk penah melakukan pelanggaran etika dalam berbisnis yang ditandai dengan melakukan ekspoitasi secara besar-besaran pada sumber daya air yang terletak di Polanharjo, Klaten, Jawa Tengah yang melanggar kode etik yang bersinggungan dengan tanggung jawab sosial sebagai perusahaan dalam mengelola sumber daya alam. Dan mengingkari hakikat demokratis yang terdapat pada pasal 33 UUD 1945. Yang menyatakan bhawa dalam pengelolaan sumber daya alam tidak dilakukan dengan benar dan mengedepankan factor keuntungan bagi perusahaan, sedangkan untuk masyarakat yang berada tinggal disekitar pabrik tersebut masih mengalami kesulitan dalam mendapatkan air bersih . Dengan melalui evaluasi dan perbaikan dalam manajemen perusahaan Aqua membuat program baru yang berkontribusi dalam kelestarian lingkungan dan pemberdayaan manusia dengan program "Aqua Lestari" dan "Satu untuk Sepuluh". Dalam hal ini dapat disimpulkan bahwa Aqua melakukan usaha untuk memperbaiki kesalahan dalam etika berbisnis dengan melakukan kegiatan CSR. Saran penulis dari hasil analisis diatas yaitu Aqua diharapkan lebih memperhatikan kode etik dan tanggung jawab sosial Aqua sebagai perusahaan dalam menjalakan produksinya. Agar sumber daya yang digunakan dapat dimanfaatkan secara berkesinambungan sehingga dalam melakukan ekspoitasi sumber daya alam harus disertai tindakan perlindungannya. Kegiatasn yang dilakukan untuk mendukung pengembangam lingkungan hidup yaitu harus dilakukan dengan cara yang dapat dilakukan oleh semua pihak yaitu:

1. Dalam melakukan pemanfaatan sumber daya harus sangat berhati-hati dan efisien seperti penggunaan air tanah dan udara.

2. Dalam melakukan produksi baiknya menggunakan bahan pengganti seperti hasil metalurgi yang berupa campuran.

3. Menggunakan metode dalam melakukan proses produksi secara efisen dan melakukan daur ulang.

4. Melakukan penerapan etika lingkungan agar interaksi antara manusia dengan alam berjalan harmonis.

\section{DAFTAR PUSTAKA}

Alakavuklar O \& Alamgir F. 2018. Ethics of Resistance in Organisations: A Conceptual Proposal. Journal Business Ethics. 31-34

Amirudin S., Ali H. 2017. Social Solidarity Baduy Tribe for Development of the Cultural Tourism and Marketing Local Crafts in Lebak Regency Banten Province.. International Journal of Applied Business and Economic Research (IJABER). 5

Ashshidiqy, N., Ali, H. 2019. Penyelarasan Teknologi Informasi dengan Strategi Bisnis. Jurnal Ekonomi Manajemen Sistem Informasi, 1(1), 51-59.

Azwar S. 2013. Metode Penelitian. Yogyakarta(ID): Pustaka Pelajar.

Bertens K. 2000. Etika. Jakarta(ID): Gramedia Pustaka Utama

Bertens K. 2007. Etika. Jakarta(ID): PT Gramedia Pustaka Utama.

Bourdeau. 2004. The Man-Nature Relationship and Environmental Ethics. Journal of Environmental Radioactivity, Vol 72, 9-15 
Chen S. 2018. Multinational Corporate Power, Influence and Responsibility in Global Supply Chains. Journal Business Ethics. 365-375

Corner P. 2009. Workplace spirituality and business ethics: Insights from an Eastern spiritual tradition. Journal of Business Ethics. Vol 85, 377-389.

Embse V dan Wagley A. 1988. Managerial Ethics Hard Decisions on Soft Criteria. Advance Managemen Jouurnal,

Fahmi I. 2013. Etika Bisnis: Teori Kasus, dan Solusi. Bandung(ID): Alfabeta.

Griffin R. dan Ronald. 2009. Business, 8th Edition, Pearson International Edition, New Jersey: Prentice Hall

Jeffrey C., Dilla W. and Weatherholt N. 2004. The impact of ethical development and cultural constructs on auditor judgments: a study of auditors in Taiwan. Business Ethics Quarterly, Vol. 14 No. 3, pp. 553-579.

Keraf A. 1998. Etika Bisnis (Tuntutan dan Relevansinya). Yogyakarta(ID): Kanisius.

Kusmiarti P. 2020. Implementasi Etika Bisnis Dan Good Governance Pada Perkebunan Kelapa Sawit PT. BUMITAMA GUNAJAYA ARGO. Jurnal Ekonomi Dan Managemen Sistem Informasi, 1., (3)., 196-210.

Mirza M. 2020. Prinsip- Prinsip Good Corporate Governance Dan Bussines Ethics Pada PT. Unilever. Jurnal Ekonomi Dan Management Sistem Informasi, 1., (3)., 261-271.

Monga M. 2007, Managers' moral reasoning: evidence from large Indian manufacturingorganisations. Journal of Business Ethics. Vol. 71 No. 2, pp. 179-194, available at: doi:http:// dx. doi.org/10.1007/s10551-006-9133-2.

Pawito. 2007. Penelitian Komunikasi Kualitatif. Yogyakarta(ID): Pelangi Aksara Yogyakarta

Sinour Y. 2010. Etika Bisnis. Jakarta : Yayasan Pustaka OborIndonesia

Sugiyono. 2013. Metode Penelitian Pendidikan Pendekatan Kuantitatif, Kualitatif, dan R\&D. Bandung(ID): Alfabeta

Sumaryono E. 1995. Etika Profesi Hukum, Norma Bagi Penegak Hukum, Yogyakarta(ID): Kanisius.

Suseno, F. 1987. Etika Dasar: Masalah-masalah Pokok Filsafat Moral. Yogyakarta(ID): Kanisius

Sutrisna D. 2010. Etika Bisnis : Konsep Dasar Implementasi dan Kasus. Bali(ID): Udayana University Press.

Velasquez M. 2005. Etika Bisnis, konsep dan kasus -edisi 5.Diterjemahkan: Ana Purwaningsih,Kurniato dan Totok Budisantoso. Yogyakarta(ID): ANDI. 